\title{
A sensitivespectrophotometric determination of tadalafil in pharmaceutical preparations and industrial wastewater samples
}

\author{
NiefRahmanAhmed*
}

Received 24, May, 2012

Accepted 4, December, 2012

\begin{abstract}
A simple, accurate, precise, rapid, economical and a high sensitive spectrophotometric method has been developed for the determination of tadalafil in pharmaceutical preparations and industrial wastewater samples, which shows amaximum absorbance at $204 \mathrm{~nm}$ in 1:1 ethanol-water. Beer's law was obeyed in the range of $1-7 \mu \mathrm{g} / \mathrm{mL}$,with molar absorptivity and Sandell's sensitivity of $0.783 \times 10^{5} \mathrm{l} / \mathrm{mol} . \mathrm{cm}$ and $4.97 \mathrm{ng} / \mathrm{cm}^{2}$ respectively, relative standard deviation of the method was less than $1.7 \%$, and accuracy (average recovery \%) was $100 \pm 0.13$. The limits of detection and quantitation are 0.18 and $0.54 \mu \mathrm{g} . \mathrm{ml}^{-1}$, respectively. The method was successfully applied to the determination of tadalafil in some pharmaceutical formulations (tablets) and industrial wastewater samples. The proposed method was validated by sensitivity and precision which proves suitability for the routine analysis of tadalafil in true samples.
\end{abstract}

\section{Keywords:Tadalafil,Spectrophotometry,Pharmaceuticals,Industrialwastewater}

\section{Introduction}

Tadalafil: (6R-trans)-6-(1,3-

benzodioxol-5-yl)- 2,3,6,7,12,12a-

hexahydro-2-methyl-pyrazino [1',
2':1,6] pyrido[3,4- $b$ ]indole-1,4dione..Populary known as Cialis and having the following structural formula,Fig(1).

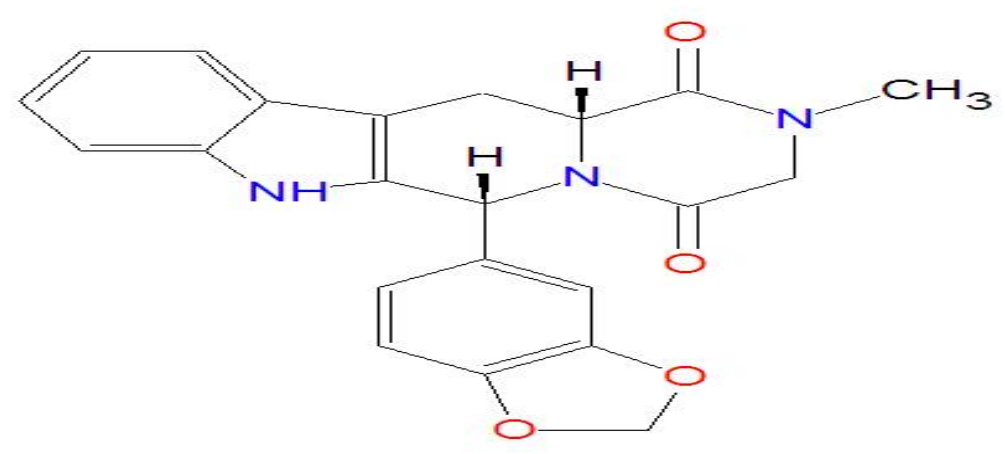

$\mathrm{C}_{22} \mathrm{H}_{19} \mathrm{~N}_{3} \mathrm{O}_{4}=389.409$

Fig(1) :Chemical structure of tadalafil

*Department of Environmental Technology, College of Environment, Universitv of Mosul. Mosul. Iraa 
Tadalafil is a phosphor diesterase type 5 inhibitor which is used in the management of erectile dysfunction.It is not officially included in any of the pharmacopoeias .It is listed in the Martindale(complete drug reference ) [1].Extensive literature survey revealed that the determination of the drug in pure and dosage forms are not officially in anypharmacopoeia and therefor, require much more investigation. There are severalmethods for determination of tadalafil such as HPLC [ 2-8],HPLCEIMS [9] , capillary electrophoresis [10] ,spectrophotometry [11-14] ,densitometry [ 15], and by electro spray tandem mass spectrometry (ESI-MS-MS) [ 16] .The ultraviolet spectrophotometric method is used in industrial laboratories because of its simplicity,selectivity, as we know only two reports have been mentioned in the literaturefor the determination of tadalafilby UV method which was used at $284 \mathrm{~nm}$ [12,14] .For this reason, an attempt has been made to develop another UV method for determination of tadalafil in pharmaceutical preparations and environmental wastewater samples with higher absorption band at $204 \mathrm{~nm}$.

\section{Methodology}

\section{Apparatus}

$$
\text { Spectro-scan } 50 \quad \text { UV- }
$$
visible(SedicoLtd,Cyprus), (double beam) spectrophotometer with $1.0 \mathrm{~cm}$ quartz cells was used for absorption measurements.

\section{Reagents}

All chemical used were of highest analytical grade and the tadalafil was provided from the state company for pharmaceutical industries (NDI) Mosul-Iraq.
Ethanol:Water $(1: 1)(\mathrm{v} / \mathrm{v})$ was used as a solvent.

\section{Tadalafil standard solution $25 \mathrm{mg} / \mathrm{L}$ $\left(4.3 \times 10^{-5} \mathrm{M}\right)$ :}

This solution was prepared by dissolving $25 \mathrm{mg}$ oftadalafil in 1000 $\mathrm{ml}$ of $1: 1$ ethanol- distilled water in a volumetric flask.

\section{Recommended procedure}

From the absorption maxima,calibration curve was constructed in the concentration range of 1-7 $\mu \mathrm{g} / \mathrm{ml}$.The absorbance was measured at $204 \mathrm{~nm}$ against ethanolwater $1: 1$ as a blank.

\section{Procedures for pharmaceutical preparations}

For the determination of tadalafil in tablet preparations, and inorder to minimize a possible variation in the composition of the tablets.A mixed content of 20 tablets of the brand, was weighed and grounded to fine powder, then the powder equivalent to $25 \mathrm{mg}$ of tadalafil was stirred well with about $90 \mathrm{ml}$ of 1:1 ethanol-water for 20 minutes and the volume was completed to $100 \mathrm{~mL}$ with distilled water ,filtered through whatman No. 41 filter paper and $10 \mathrm{ml}$ of this solution was diluted to $100 \mathrm{ml}$ by ethanol - distilled water $1: 1$ to get $25 \mu \mathrm{g} / \mathrm{ml}$ solution and aliquot of this solution was treated as described above for recommended procedure. 


\section{Procedure for real water samples}

To demonstrate the practical applicability of the proposed method, real water samples were analyzed by this method.Industrial waste water from the state company for drug industries and medical appliances Mosul-Iraq, were fortified with the concentrations in the range of $2,4,6$ $\mu \mathrm{g} / \mathrm{ml}$ of tadalafil .The fortified water samples wereanalyzed as described above for recommended procedure and the concentration was calculated by using the calibration curve of this method.

\section{ResultandDiscussion}

The standard solution of tadalafil $(5 \mu \mathrm{g} / \mathrm{mL})$ was scanned in the range of 200-400nm which shows two maxima located at 204 and $284 \mathrm{~nm}$ Fig 2. The higher absorption bandat 204 nm. Therefore $204 \mathrm{~nm}$ wavelength was selected for the construction of calibration curve.

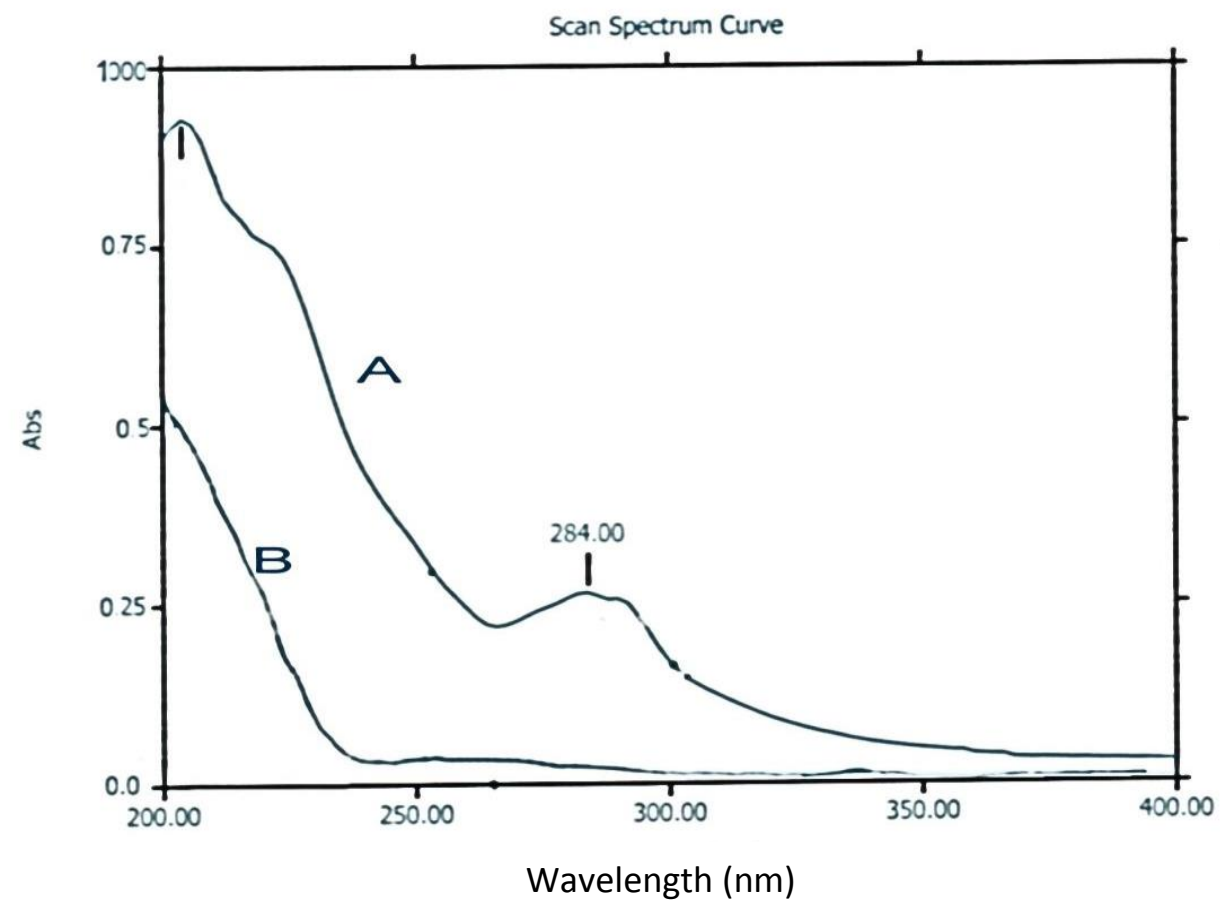

Fig (2);-Absorption spectra of (A)5 $\mu \mathrm{g} / \mathrm{ml}$ tadalafil against blank (1:1 ethanol : water), (B) blank against distilled water.

Beer' $s$ law was obeyed in the concentration range of $1-7 \mu \mathrm{g} / \mathrm{mL}$ ( Fig 3) with correlation coefficient of 0.999.The conditional molar absorptivity was found to be $0.783 \times 10^{5} 1 / \mathrm{mol} . \mathrm{cm}$, and the Sandell's sensitivity was $4.97 \mathrm{ng} / \mathrm{cm}^{2}$. The limit of detection (LOD) and limit of 
quantification(LOQ) were calculated according to the current ICH guideline as the ratio of 3.3 and 10 standard deviation of the blank $(n=11)$,respectively, and the slope of the calibration line [17].The limit of detection was $0.18 \mu \mathrm{g} / \mathrm{mL}$ and the limit ofquantification as the lowest standard concentration which could be determined with acceptable accuracy, and precision was $0.54 \mu \mathrm{g} / \mathrm{mL}$.

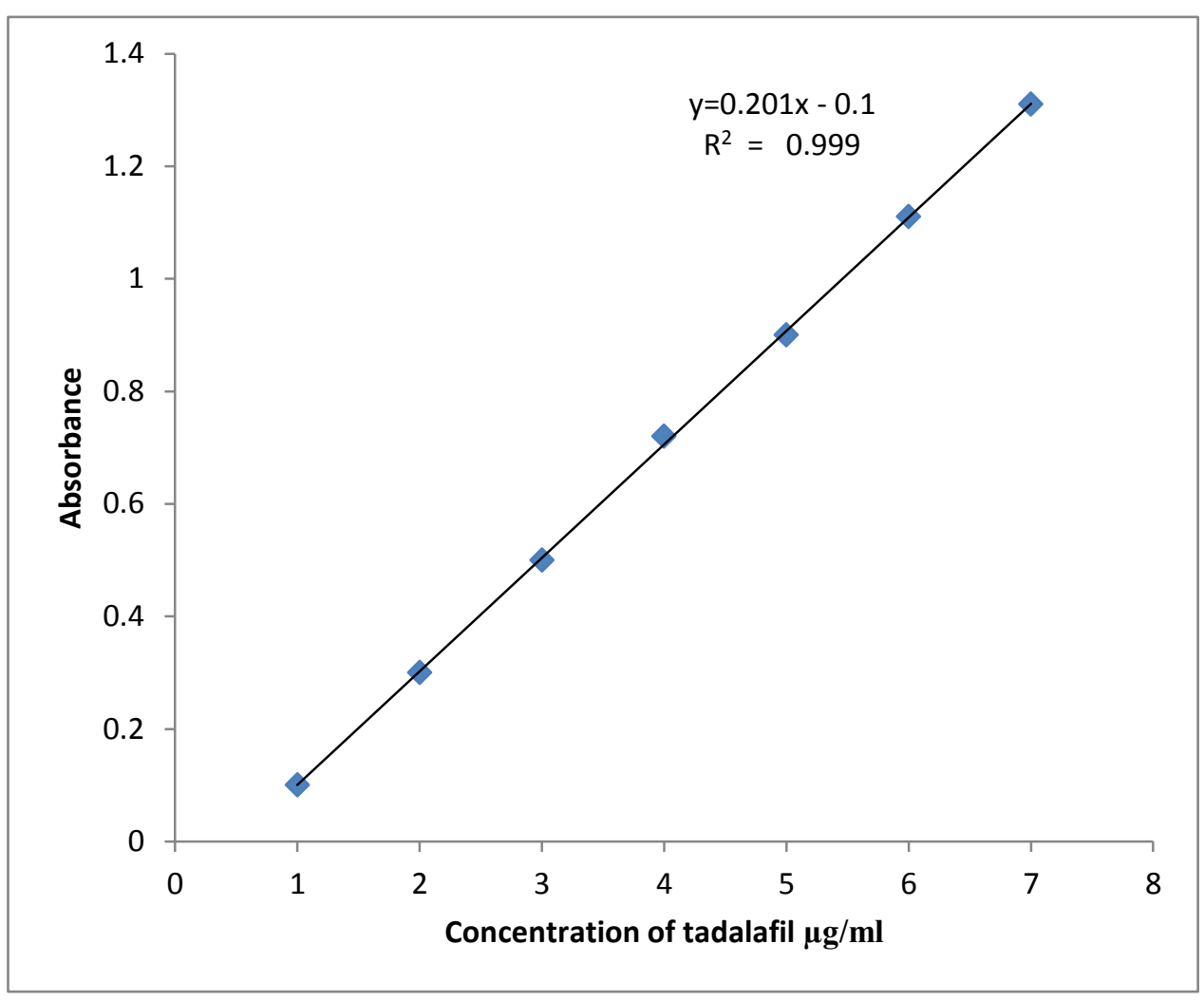

Fig. (3): Calibration graph oftadalafil.

In order to determinethe accuracy and precision of the method,a pure drug solution was analyzed at three different concentrations ,each determination being repeated six times. The relative error $(\%)$ and relative standard deviation values are summarizedin Table 1.
From Table 1 the valuesof standard deviation were satisfactory and the recoverystudies were close to $100 \%$,. The RSD\% value is less than 1.7 . 
Table( I) Accuracy and precision of the proposed method.

a: Mean of six determinations.

\begin{tabular}{|c|c|c|c|}
\hline $\begin{array}{c}\text { Tadalafil taken } \\
(\mu \mathrm{g} / \mathrm{ml})\end{array}$ & Tadalafilfound $(\mu \mathrm{g} / \mathrm{ml})$ & $\operatorname{Er}(\%)^{\mathrm{a}}$ & $\begin{array}{c}\operatorname{RSD}(\%) \\
(\mathrm{n}=6)\end{array}$ \\
\hline 2 & 2.022 & 1.1 & 1.3 \\
4 & 4.048 & 1.2 & 1.6 \\
6 & 6.072 & 1.2 & 1.4 \\
\hline
\end{tabular}

The proposed method was compared with other reportedUV spectrophotometric methods and found to besuperior,(Table 2).

Table (2):Comparison of the existing UV spectrophotometric methods with the proposed method for tadalafil.

\begin{tabular}{|l|l|l|l|}
\hline Parameters & Method 1 & Method 2 & Method 3 \\
\hline Ref & 12 & 14 & Proposed \\
\hline$\lambda$ Max $(\mathrm{nm})$ & 284.5 & 284 & 204 \\
\hline Solvents & $\begin{array}{c}\text { Methanol: } \mathrm{H}_{2} \mathrm{O} \\
80 \quad: 20\end{array}$ & Methanol & $\begin{array}{c}\text { Methanol: } \mathrm{H}_{2} \mathrm{O} \\
50 \quad: 50\end{array}$ \\
\hline Linear range $\mu \mathrm{g} / \mathrm{ml}$ & $5-30$ & $2-20$ & $1-7$ \\
\hline$\varepsilon(1 / \mathrm{mol} . \mathrm{cm})$ & $0.66 \times 10^{4}$ & $1.65 \times 10^{4}$ & $0.783 \times 10^{5}$ \\
\hline RSD\% & Less than 2 & 0.28 & Less than 1.7 \\
\hline Application & Pharmaceuticals & Pharmaceuticals & $\begin{array}{l}\text { Pharmaceuticals } \\
\text { andindustrial } \\
\text { wastewater }\end{array}$ \\
\hline
\end{tabular}

\section{Interference studies}

In order to assess the possible applications of the proposed method, the effect of substance that often accompany with tadalafil in (Tablets) were studied by adding different amount of substances to $5 \mu \mathrm{g}$ oftadalafil. An attractive feather of the method is its relative freedom from interference by the usual diluents and excipients in amounts for in excess of their normal occurrence in pharmaceutical preparations. The results are given in Table (3). 
Table (3) Determination of $5 \mu \mathrm{g}$ of tadalafil in the presence of excipients and other substances.

\begin{tabular}{|c|c|c|c|c|}
\hline Interfering substances & $\begin{array}{c}\text { Amount added/mg of } \\
\text { interfering }\end{array}$ & $\begin{array}{c}\text { Amount of drug } \\
\text { found } \mu \mathrm{g}\end{array}$ & $\begin{array}{c}\mathrm{Er} \\
(\%)^{\mathrm{a}}\end{array}$ & $\begin{array}{c}\mathrm{RSD} \\
\%\end{array}$ \\
\hline Lactose & 40 & 5.06 & 1.2 & 0.71 \\
\hline Microcrystalline cellulose & 20 & 4.96 & -0.8 & 0.64 \\
\hline Corn starch & 30 & 4.97 & -0.6 & 0.78 \\
\hline Povidone & 30 & 5.05 & 1.0 & 0.79 \\
\hline Magnesium stearate & 40 & 5.07 & 1.4 & 0.91 \\
\hline $\begin{array}{c}\text { Hydroxylpropyl methyl } \\
\text { cellulose }\end{array}$ & 40 & 4.97 & -0.6 & 0.93 \\
\hline $\begin{array}{c}\text { Poly ethylene glycol } \\
\text { Titanium dioxide }\end{array}$ & 20 & 5.01 & 0.2 & 0.91 \\
\hline
\end{tabular}

*Average of six determinations.

\section{Analytical application}

Theproposed method was satisfactorily appliedto the determination of tadalafil in its pharmaceutical preparations tablets and wastewater samples, the results of the assay of the pharmaceutical preparations revels that thereis close agreement between the results obtained by the proposed method and the labelclaim, Table4and the results of water samples Table 5 show that the recovery values obtained were closed to $100 \%$

\section{Table(4): Determination of tadalafil in pharmaceutical formulations}

\begin{tabular}{|l|c|c|c|}
\hline $\begin{array}{r}\text { Pharmaceutical } \\
\text { formulations }\end{array}$ & $\begin{array}{c}\text { Labelamount } \\
(\mathrm{mg})\end{array}$ & Founded $^{*}(\mathrm{mg})$ & Recovery\% \\
\hline Tablets & $20 \mathrm{mg} / \mathrm{tab}$ & 19.96 & 99.8 \\
& $10 \mathrm{mg} / \mathrm{tab}$ & 10.02 & 100.2 \\
\hline TTadananine(NDI)] & & & \\
\hline
\end{tabular}

*mean value of ten determinations 
Table(5): Determination of tadalafil in wastewater samples

\begin{tabular}{|c|c|c|c|}
\hline Wastewater samples & Added $\boldsymbol{\mu g} / \mathbf{m l}$ & Found* $(\boldsymbol{\mu g} / \mathbf{m l})$ & Recovery $\%(\mathbf{n}=\mathbf{1 0})$ \\
\hline \multirow{2}{*}{ Industrial wastewater } & 2 & 2.02 & 101 \\
& 6 & 3.98 & 99.5 \\
& 6 & 6.08 & 101.3 \\
\hline
\end{tabular}

* mean value of ten determinations.

\section{Conclusion}

The developed method is found to be high sensitive,accurate,simple,precise and economical,and can be usedfor routine quality control analysis of tadalafil in pure form,bulk, pharmaceutical formulations and environmental wastewater samples.

\section{Acknowledgments}

The author wishes to express gratitude to his former company[ the state company ofdrug industries and medical appliance (NDI) Nineveh Iraq for providing gift samplesoftadalafil standard material and tablets.

\section{References:}

1- SwetmanS.C;Martindale.2005.The complete Drug References, 34 Edn,Pharmaceutical Press London,p.1751.
2- Reddy.B,Amarnadh.K and Reddy. M . 2010.; Validation and stability indicating RP- HPLC

method for the determination of tadalafil in pharmaceutical formulations:Res.Pharm.Biotech.,2 (1):,1-6.

3-Aboul-Enein .H.Y and Ali.I; 2005.Determination of tadalafil in pharmaceutical preparation by HPLC using mono lithic silica column;Talanta,,65(1):,276-280.

4-Ching-Lingand Chen-His.Chou.Ch .2005. ;determination of tadalafil in small volumes of plasmaby HPLC with UV detection ;J.Chromato. B,822(1):,278-284.

5-Rabbaa-

Khabbaz.L.andAbiDaoud.R;.2006.. Asensitive and simple HPLC method for quantification of 
tadalafilin human serum;J. A.Res,6(1):,170-175.

6-Barot.T,Patel. 2010.Determination of tadalafil in pure powder and tablet dosage form byHPLC,JAOAC,93(2):516-522.

7-Farthing .C, Farthing .D, Koka. S, Larus. T, Fakhry. I, Xi. L, Kukreja. R, Sica .D, and Gehr .T 2010 A simple and sensitive HPLC fluorescence method for etermination of tadalafil in mouse plasma.; J. Chromat. B. Anal. Technol. Bio .Life.Sci, 878(28):,2891-2895.

8-Satish.A,Natvarlal.J.2011 .HPTLC method for determination of tadalafil in tablet dosage form;AJPTR, 1(3):,138-146.

9-

Zhu.X. Xaiao.S,Chen.B,Zhang.F,Yao.S,W au.Z and Hau.H 2005.Simultaneous determination of sildenafil,vardenafil and tadalafil as forbidden components in natural dietary supplements for male sexual potency by HPLC electro spray ionization mass spectrometry;J.Chromatogr A,1066,89-95.

10-Aboul-Enein .H.Y and Ali.I.2004. .Validated method for tadalafil analysis in pharmaceutical preparations by capillary electrophoresis;Chromatographia,6 0,187-191.

11-NesalinJ.A.,Babu.C.J,Kumar.G.V and Mani.T.T.2009.Validated extractive spectrophotometeric estimation of tadalafil in tablet dosage form ;E-J Chem,6(3):,611614.

$12-$

Anandakumar.K,Varadharajan.K,S ubathrai.R and Siavn.G 2010 .Estimation of tadalafil in bulk and formulation by uv -visible spectrophotometry;Asian. J. Res. Chem,3(1),54-58.

13- Ali .A,andAymana.G 2011 Spectrophotometric determination of tadalafil in pure and dosage forms ; Chem. Indus. Chem. Engineer.Quat 17 (2) 125-132.

14-Mohmmad.Y,

Gowri.D.,Pragatikumar.Band

Shahul.H $2010 \quad$ UV

Spectrophotometric method for the estimation of tadalafil in bulk and tablet dosage form; E-JChem, 7(3), 833-836.

$15-$

Berniati.H.T,Endang.S,Dwi.S.S,Sit i.C, Farina.W.K and Gunawan.I,2006Densitometric determination of tadalafil citrate in tablets:Validation of the method ;J.Liq Chrom.Relat.Tech,29,27532765.

16-Abdel-

Hamid.M.E.2006..Determination of sildenafil ,tadalafil and vardenafil in tablets and adulterated herbal product by ESIMS-MS;J.Liq.Chrom.Relat Tech.,29(4):,591-603.

17- Valcarcel. M.2000.Principles of Analytical Chemistry ,Atext book, 
Spring verlager ,Berlin Heidelberg,

First edn.69, 207.

\section{التقدير الطيفي للتدالافيل في المستحضرات الصيدلانية والمياه الصناعية|لمطروحة المسنة}

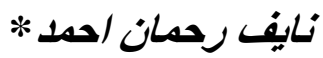

\section{*جامعه الموصل كليه البيئة}

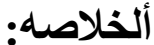

تمتطوير طريقة طيفية في المنطقة فوق البنفسجية تمتاز بالبساطة والدقة والضبطو السرعة و الحساسية العالية

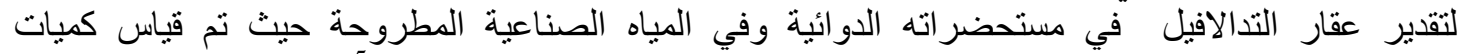

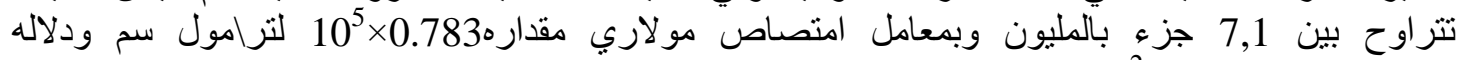

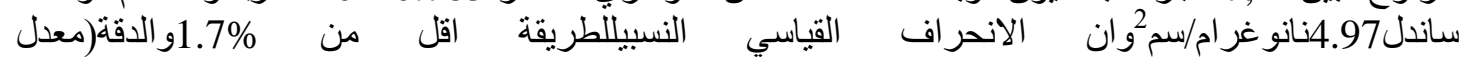

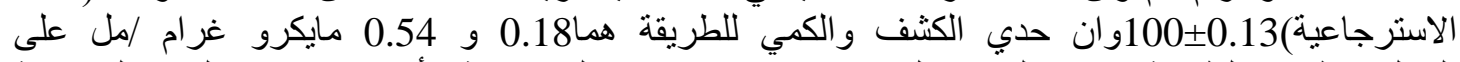

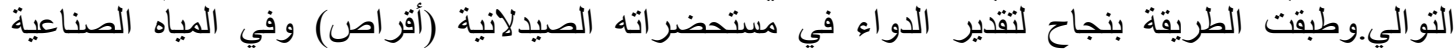
المطروحة و اقترحت الطريقة للنحليل الروتيني كونها ذات حساسية عالية وبسيطة وسريعة وذات دقة وبية جيدة التية 